\title{
Examining the Factors Influencing Orthopedic
} \section{Physician's Decision to Purchase Medical Devices: Evidence from Kuwait}

\author{
Mohamed Gendia (D)', Hamed M Shamma ${ }^{2}$ \\ 'Al Sayer Medical Company, Shuwaikh Free Trade Zone, Kuwait; ${ }^{2}$ Marketing, The American University in Cairo, Cairo, Egypt \\ Correspondence: Mohamed Gendia, Al-Salmiya, Qatar St, Kuwait, Tel +965975I8I09, Email mgendia_02@msm-kuwait.com
}

\begin{abstract}
Purpose: It is explanatory and descriptive research to explain the relationship among factors influencing the orthopedic physician's decision of purchasing medical devices and equipment.

Methods: Quantitative method will be used in this study as all heads of departments in MOH hospitals refused to make one-to-one interviews and suggested only questionnaires that will be high in confidentiality.

Results: For the first question: What is the ranking of factors that influence orthopedic physician decision in purchasing medical devices and equipment in $\mathrm{MOH}$ hospitals in Kuwait? According to HB analysis, the most preferred attribute is implant review in a journal and the lowest preferred factor is product training. Moreover, Brand was the second preferred attribute followed by leader influence. Surprisingly, price came after all these attributes. Physicians ranked technical support and sponsorship in the fifth and sixth places. For the second question: How can marketing and sales management predict orthopedic physicians' decisions before designing product proposals? This will assist M\&S department in creating proposals that satisfy orthopedic physicians through expecting their decisions on various alternatives.

Conclusion: There is a good opportunity for all medical devices companies, after discussion with SMEs, either for growth or leaving stagnation phase. However, SMEs have no real understanding of what factors matter to the orthopedic physicians' decision in purchasing medical devices and equipment. Thus, one of the goals of this research is to give M\&S departments in medical devices companies with recommendations that will help them in forming attractive product offers to orthopedic physicians in MOH hospitals in Kuwait. Moreover, predicting the response from them in the future. In addition, four simulation scenarios have been conducted in this research to reach the best economic offer that maintains physicians attracted.
\end{abstract}

Keywords: medical devices, decision-making, consumer behavior, medical equipment, orthopedic physician, conjoint analysis, medical marketing

\section{Introduction}

With the growing competition in the medical devices field, medical devices companies seek a better understanding of their target customers' preferences to provide the best service and to promote the most convenient product offering matching the customers' demands and expectations. In the medical devices industry, although patients are the final-stage customers of any medical device, the patients do not play a direct role in the procurement cycle of those devices. Physicians are considered the main end-users for medical devices companies. Undoubtedly, the Marketing and Sales Departments' main goal is to achieve more sales, profit, or market share that is where studying the target customers play a significant role. Many researchers have studied the factors influencing the customer decision to purchase a certain product but in medical orthopedic devices, there is a scarcity of studies on the factors influencing the orthopedic physicians' decision of purchasing medical devices and equipment. Consequently, the study's focus is to enlighten the marketing and sales $(M \& S)$ departments in the medical devices companies about the factors that matter the most to the orthopedic physicians in governmental hospitals in Kuwait. 


\section{Shares of Preference}

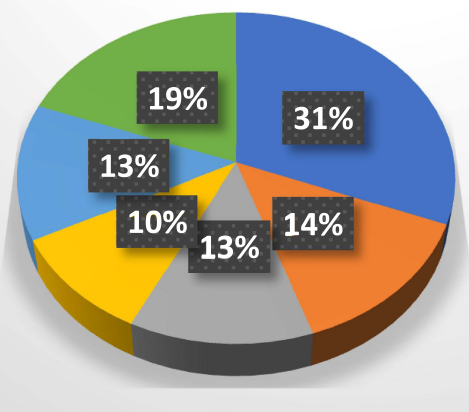

- Reference1

- Proposal 1

- Proposal 2

Proposal 3

- Proposal 4

proposal 5

Figure I Share of preferences percentages of each proposal.

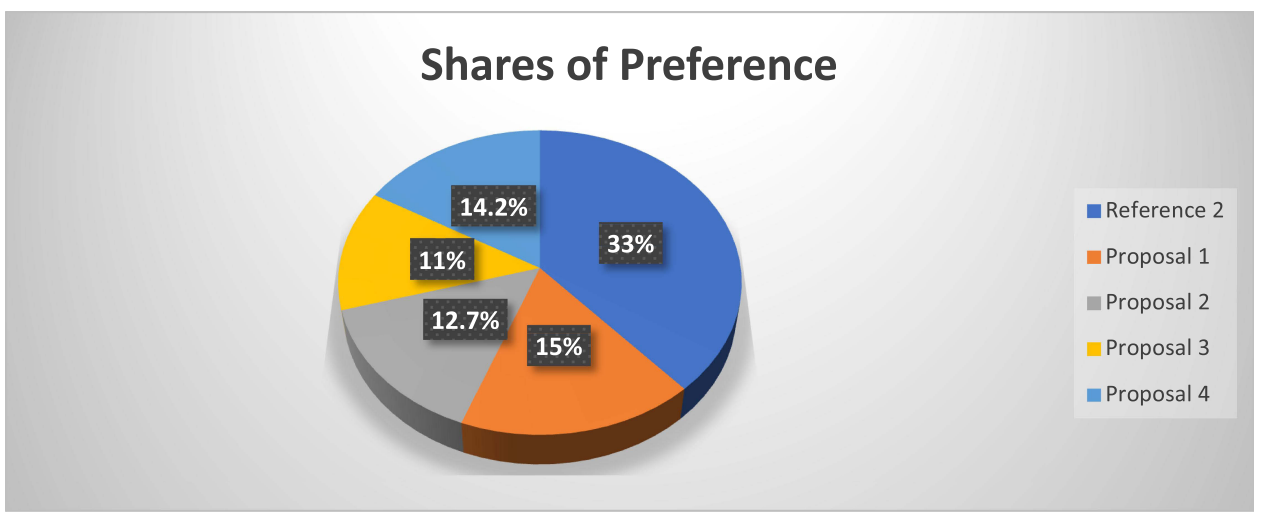

Figure 2 Share preference of second simulation.

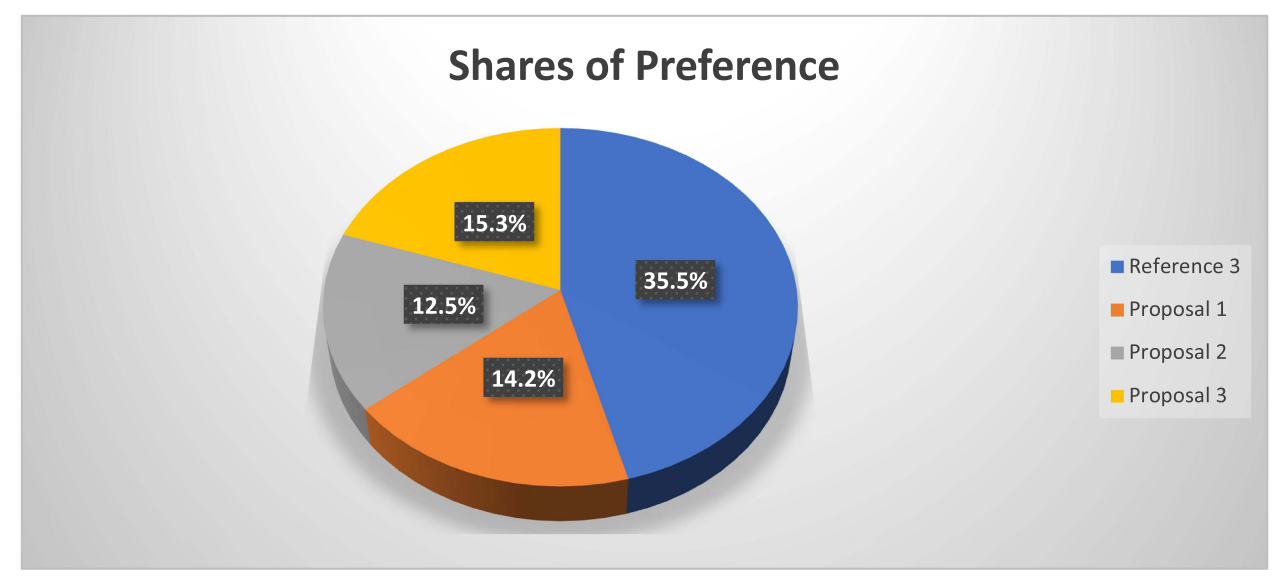

Figure 3 Share preference of third simulation.

\section{Research Relevance to the State of Kuwait}

Kuwait spends 3\% of its Gross Domestic Product (GDP) on the healthcare sector compared to 9\% of GDP for countries with advanced economies. This situation triggered Kuwait to allocate 4.2 billion (bn) United States dollars to build nine more $\mathrm{MOH}$ hospitals under the year 2035 vision. Moreover, Kuwait has awarded projects worth $\$ 11$ bn in the 
construction of new infrastructure for healthcare as it seeks to prioritize the transformation of its healthcare sector (tenlivegroup, 2018). ${ }^{1}$ However, in nominal terms, health spending increased by more than double over the period, from $\$ 2.28$ bn in 2006 to $\$ 5.08$ bn in 2013 . Government health expenditure makes up the vast majority of this figure, accounting for over than $82 \%$ of the total health spending in 2013 (oxfordbusinessgroup, n.d.). ${ }^{2}$

In the light of the previous changes in Kuwait MOH and after discussion with Subject Matter Experts (SMEs), they stated that medical devices and equipment companies that seek more market share to advance their competitive advantages, should take this opportunity and engage with the physicians by understanding their preferences. Consequentially, this research will rank the most crucial factors influencing the orthopedic physicians' decision of purchasing medical devices and equipment from medical devices companies dealing with MOH hospitals in Kuwait.

\section{Problem Definition}

Parallel to the previously mentioned updates about the expected growth of the $\mathrm{MOH}$ sector in Kuwait, and after validation with SMEs, they clarified two different viewpoints of medical devices companies management. Some companies aim for more growth in the upcoming years from Kuwait MOH hospitals. On the other hand, some companies are struggling from sales stagnation and need to leave the stagnation phase by gaining more market share. Moreover, both do not have a clear realistic understating of what factors matter the orthopedic physicians' decision of purchasing medical devices and equipment. Also, little is known about the factors associated with physician preferences in a product and its vendor. ${ }^{3}$ Moreover, there are no theories or conceptual frameworks that were specifically designed to explain the influence of physicians' motivation on medical devices adoption in a healthcare context. ${ }^{4}$

\section{Research Objective}

This study objective is to assess the most crucial factors that influence the orthopedic physicians' decision while purchasing medical devices and equipment from medical devices companies in Kuwaiti MOH hospitals, which enable M\&S department to build a realistic business strategy and better allocate the marketing budget by spending more on the real factors that influence decision and decreasing the money-wasting on less influencing factors, which at the end will positively influence the company profit. In addition, it presents a simulation tool that can expect orthopedic physicians' decisions in case of having many offers by pointing to the trade-offs of those physicians during the evaluation stage of the submitted offers before the final purchase decision.

\section{Literature Review}

Physicians are the ones that understand patient needs and therefore, the role of physicians as decision-makers is stressed as important. ${ }^{5}$ Also, physicians are the primary decision-makers when it comes to medical device purchases and patient treatment. ${ }^{3}$ Their control is emphasized through the healthcare institutions purchasing process and the decision-makers in the procurement and materials departments. ${ }^{3}$ Another study argued regarding the challenges that healthcare sector policymakers have in curbing the costs of purchases and at the same time ensuring high-quality service. ${ }^{6}$

The objective of the study is to assess the factors and their values that influence orthopedic physicians in purchasing medical devices and equipment. This will lead to developing a conceptual framework and discussing the variables that are used in developing the framework. Later, these assessed factors will be utilized as variables to be measured and ordered by conjoint analysis to find the real answer to the research objective. This answer is very significant to the orthopedic medical companies in Kuwait to better allocate budget and to put realistic marketing and strategic plans to get more sales in the future.

\section{Kuwait's Overview}

Kuwait's public healthcare segment represents around $80 \%$ of the healthcare spending in the country, while private hospitals account for almost $20 \%$ of healthcare spending. The MOH announced on October 2018 that a $\$ 4.42$ billion project to replace or enlarge nine hospitals (five general hospitals and four specialized hospitals) within the next 10 years. It is expected that 15,000 HCPs will be required in the MOH hospitals alone by 2030. Kuwait's MOH manages all healthcare services related to pharmaceuticals, medical devices and equipment business for all MOH hospitals. ${ }^{7}$ 


\section{Global Orthopedics Market Overview}

The orthopedic medical devices market is a part of the medical devices market; generally medical devices market is a growing market. According to the S\&P Capital industry report, the global orthopedic devices market is estimated to reach $\$ 42$ billion by 2020 at a Compound Annual Growth Rate (CAGR) of 3.2\%. ${ }^{8}$

\section{Definitions}

\section{Orthopedic Surgeon}

A doctor who performs surgical intervention for treating trauma and affections of the musculoskeletal system, which consisted of bones, joints, ligaments, tendons, muscles in addition to nerves. ${ }^{9}$

\section{Medical Devices}

An article, instrument, apparatus, or machine that is used in the prevention, diagnosis, or treatment of illness or disease, or for detecting, measuring, restoring, correcting, or modifying the structure or function of the body for some health purpose. Typically, the purpose of a medical device is not achieved by pharmacological, immunological, or metabolic means. ${ }^{10}$

\section{Decision-Making}

The action taken by people toward solving their problems is known to be named the decision-making which will usually result in finding satisfactory solutions to those problems. Decision-making is considered an emotional process that may be subjected to rationality or even irrationality. It is also defined to be the real choice from many alternatives. They stated that decision-making is considered an important stage in the planning of the management of any company or even at the personal level especially when choices will reflect on gaining certain goals such as money. ${ }^{11}$

An older study made by Oliveira ${ }^{12}$ describes decision-making as the way that managers detect to resolve the problems to get benefits from the available opportunities. There are seven steps in the decision-making process, these steps start with identifying the problem or the opportunity, putting a clear objective, increasing the number of alternatives, weighing these alternatives, reaching decisions, implementing the decision, and finally assessing the outcomes.

\section{Procurement}

Hatz et $\mathrm{al}^{4}$ emphasized that physician power in procurement was strong that they could make the decisions even when the cost of the medical devices was higher compared to other products. Therefore, the physicians were given the decisionmaking power in choosing the product and the manufacturer.

Another study by Lingg et $\mathrm{al}^{13}$ focused on orthopedic specialists and high-risk medical devices (HRMDs) such as knee prosthesis indicated for a knee joint replacement. There are various people involved in the selection and ordering of medical devices. Physicians play a strong role in their recommendations in the purchase of such medical devices. The decisions that are made by physicians will have a major impact on the purchase decision. Moreover, Felgner et $\mathrm{al}^{14}$ carried out a study to identify factors that impact physician decisions in adopting new technologies. They carried out interviews with physicians to understand how they make decisions and their choice of product and vendors. The findings showed that the physicians they interviewed had the power to choose the product and vendor of their choice. The hospital management provides the freedom of choice to the physicians in making decisions about procuring new technologies and purchasing medical devices.

\section{Kuwait Orthopedic Medical Devices Procurement Cycle}

Orthopedic surgeons play an influential role in the procurement cycle of medical devices purchasing in $\mathrm{MOH}$ hospitals. First, orthopedic surgeons in Kuwait $\mathrm{MOH}$ hospitals are the ones who write the tenders' specifications in a request form. Second, the requests are submitted to Central Medical Stores of MOH CMS administration to issue tenders' inquiries to be sent to the medical companies requesting an offer against the needed specifications. Third, medical companies submit their offers to the CMS accordingly. Fourth, the requester orthopedic physician validates the different offers from the medical companies technically and awards the tenders to the company of choice followed by submitting the award letter to CMS. Finally, CMS contact the company of choice by awarding a letter then a contract is issued 
between CMS and the medical devices company including quantities, prices, delivery schedule, and other legal terms and conditions.

From this process, it is clear that orthopedic physicians are highly involved in the choice and decision-making of purchasing medical devices and equipment in Kuwait.

\section{Cases (Best Practices) \\ First Case \\ Motivation}

Physicians are the main end-users when deciding which devices to use on patients. The huge diversity of these technologies and the frequency of their usage represent a significant portion of hospital expenses and the main contributor to the increase of health care costs. Thus, physicians' decisions on medical devices and suppliers are stressed as a cornerstone in efforts to contain costs.

One of the prominent studies involving orthopedic specialists is made by Burns et $\mathrm{al}^{3}$ who focus on factors that influence orthopedic physician preferences. They indicate that the major cost of the healthcare sector expenses comes from the purchases and implementation of medical devices. The survey targeted the orthopedic physician who makes at least 12 surgeries per year in the Commonwealth of Pennsylvania. This survey found out the company preferred by each physician in addition to the influential factors that led to the selection of a company over others. The total number of the final samples was 492 physicians, while 201 responded to the survey. The study result showed four main factors that are implant-related features, vendor-related features, sales/service/training, and financial/cost factors. Finally, physicians' preferences are highly influenced by technology/implant features and sales/service features, while implant cost was less important.

\section{Second Case}

\section{Motivation}

To ensure an efficient pricing strategy and coverage with scientific proof in Germany, certain new technologies have been subject to value examination since 2016 to decide about their reimbursement. However, this is a change to the German approach, which used to be limited when it came to reimbursement to a few devices. As physicians came to know this policy, the target was to understand physicians' purchasing decisions of new medical devices and to detect their evaluation on the review and price under the umbrella of the reimbursement systems. Felgner et $\mathrm{al}^{14}$ conducted a study to understand physicians' decision-making on adopting new medical technologies. One of the authors interviewed 23 physicians in Germany for a period of 5 months starting in April 2017. These interviews were via phone calls or personal interviews.

The data collected from these interviews were analyzed to find the factors influencing the physicians' decisions. Finally, they found 52 factors, which are categorized into eight groups: technology, evidence base, state of medical care, manufacturer, regulation, hospital, individual and patient factors.

Based on Felgner et $\mathrm{al}^{14}$ study results, the physicians had the power to choose the product and vendor of their choice. Physicians considered the service provided by medical companies in their decision-making. Also, physicians assessed the evidence base when deciding whether to adopt a technology. Moreover, the state of medical care, which includes medical guidelines. was the first factor influencing the adoption of medical devices by physicians.

Additionally, the adoption and utilization of new technologies should be based on gathering knowledge from realworld evidence. Physicians expect a high level of service, which will enhance their learning curve by increasing experience in this new technology utilization; thus, this emphasizes the need for training when using medical devices. Finally, physicians reported their interest in something new and extraordinary as a driver to utilize new technology.

\section{Business Case from Kuwait}

The following data are retrieved from the confidential annual sales report of a company (x) in Kuwait that employs 40 people, while a stagnation of sales to less than $40 \%$ of the forecasted value is noticed in the last 2 years; this stagnation also is noticed in some of the private medical devices companies dealing with MOH hospitals as well. The company was achieving \$4 million and \$ 4.3 million in 2014 and 2015, respectively. 
It has three lines of business, which are line 1, line 2, and line 3. It has three main contracts with MOH hospitals, which are contract (A), contract (B), and contract (C). Contract (A) that was worth approximately $\$ 6.3$ million is valid till September of 2019, contract (B) value is \$ 6.9 million is valid till July 2020 while contract (C) value is $\$ 7.3$ million and was expected to be signed by 2021 . The terms and conditions of these contracts state that the contract validity is 3 years from the date of contract signing and the company has to deliver one-third of the total contract value after signing the contract, while the rest two-thirds are as per the surgeons' request. In 2016, one-third of these lines from the contract (A) was $\$ 1$ million, $\$ 600,000$, and $\$ 500,000$ respectively with a total of $\$ 2.1$ million, while in 2017 the total sales value was $\$ 2.3$ million, which is one-third of the contract (B). The Key Opinion Leaders (KOL) surgeons and store managers are not requesting two-thirds of these two contracts, which are approximately $\$ 9$ million and even planning to decrease the first delivery of the contract (C) to half of one-third which will reflect negatively on sales, marketing budget, and manpower stability. On the other hand, from 2014 till now the purchasing power of these hospitals is increasing, the number of surgeons is increasing, and the number of surgeries is increasing.

This situation was the trigger to interview SMEs, who stated clearly that the orthopedic physicians are the main elements influencing sales of the medical devices companies as they are the ones putting the tenders' specifications, validate the different offers from the medical companies, using these devices, validating their efficacy, awarding the business tenders to the company of choice, judging the postoperative patient status. On the other hand, there is no previous research focusing on the orthopedic physicians' choice of purchasing medical devices and equipment in Kuwait MOH hospital. Also, SMEs highlighted that orthopedic physicians complain from private medical companies as they do not satisfy their requirements and needs. Moreover, dealing with them from a one-unit perspective depends on prices while every surgeon has his perception and need, which should be fulfilled by medical companies.

Finally, orthopedic physicians are considered the main customers of medical devices companies. Thus, their decision reflects on the companies' sales in the present time their forecast in the future.

\section{Factors Influencing the Purchasing of Medical Devices and Equipment}

Since the objective of this study is to assess the value and importance of the factors that influence the purchase of medical devices and equipment, and based on the relevant literature, the factors that lead to purchase decision-making are those factors that matter to the orthopedic physicians. These factors are summarized below and to be later treated by conjoint analysis to find the value of each factor.

\section{Brand}

A strong brand positively reflects on companies through increasing sales revenues and strengthening company reputation. ${ }^{15}$ Also, Bahadori et al ${ }^{16}$ defined a brand by its manufacturer country equity, oldness, and reputation. Also, products bearing a "Made in Germany", "Made in Switzerland" or "Made in Japan "label are commonly regarded as high quality, owing to the reputation of these countries as top world manufacturers and exporters. At the same time, "Made in Suriname" or "Made in Myanmar" labels may raise doubts about the quality of the products owing to the low country brand equity. Thus, there is a positive correlation between prescription behavior and reputation of the company and strength brand names. ${ }^{17}$

\section{Opinion Leader (Leader Influence)}

Leaders that lead opinions are skillful well-known physicians who are in powerful positions and decision-makers. These leaders distribute the informational message that companies pursue to convey through their brands as they constitute significantly valued elements like value and trust to the purchaser. ${ }^{18}$

\section{Trust}

Trust has been studied by various researchers in healthcare as Chao and Cheng ${ }^{19}$ indicate how communication, the reputation of the partner, perceived benefits, and relationship tenure plays a role in trust. Trust also impacts commitment that leads to future relationships with medical device suppliers to purchase products. 


\section{Conferences Sponsorship (Sponsorship)}

Sponsoring the physicians at medical conferences is the most influential factor which has a significant effect on raising the prescriptions for a certain product. $^{20}$

\section{Relationships with the Company Representative (Technical Support of Medical Representative)}

Device reps and some surgeons believe that reps benefit patient care, by increasing efficiency and mitigating deficiencies among operating room personnel (including the surgeons themselves). ${ }^{21}$

\section{Quality (Clinical Outcome)}

One of the success determinants of the health services providers is a correct diagnosis in which the use of quality medical equipment plays an important role, the quality of medical equipment is measured by the ease of work, the quality of output, and standards of quality. ${ }^{16}$

\section{After-Sale Service}

It is defined to be a combination of four criteria which are alternative equipment, accessory, skills of engineers, and access to engineers. ${ }^{16}$ Also, the same study results ranked after-sale service third among the factors influencing the purchase decision of medical equipment.

\section{Patient Condition}

Refers to patient age, patient weight, patient expected activity, patient bone stock, and patient's general health status. ${ }^{22}$

\section{Implant Technological Features (Scientific Evidence for Better Outcomes Which Measured as Implant Review} in Journal)

One way to find out how implant's technological features are defined is to use the criteria made by Burns et al, ${ }^{3}$ who determined seven variables that influence the orthopedic surgeon in selecting the implant of choice. These features are scientific evidence of better outcomes, outcomes in surgeons' patients, device design and ease of implantation, instruments design and ease of use, implant longevity in the patient, product reputation, and ease of switching to another vendor's product.

\section{Sales and Service Features (Product Training)}

Burns $\mathrm{et}^{3}{ }^{3}$ summarized the sales and service features into;vendor's implant training program, availability and likeability of the sales representative, follow-up, thoroughness, and knowledge of the sales representative, stability and tenure of the sales representative, ability of sales representative to augment OR staffing, ability of sales representative to improve case quality or OT efficiency, education-focused seminars/events funded by vendor, information available to patients on the Internet, experience with senior surgeon mentors during orthopedics training and finally product/vendor used during orthopedics training.

\section{Innovation}

According to Sampietro-Colom et al, ${ }^{23}$ innovation of the new medical equipment is one of the main determinant criteria in a purchase decision. Also, Burns et $\mathrm{al}^{3}$ highlighted that products innovation introduced by the medical devices companies is considered one of the influential criteria of medical devices purchasing.

A study by Chandy and Tellis ${ }^{24}$ defined product innovation as the new product that incorporates a substantially different core technology and provides substantially higher customer benefits relative to previous products in the industry. So, we consider according to physicians "more anatomical" as the opposite of "Universal or standard implant", the first is tailored to the anatomy of each patient's medical condition and the other comes in one size or design that fits all patients regardless of the situation of the patient.

"More anatomical" is innovative because it mimics the real anatomy of the patient which might reduce wear and tear on these products and improve the restoration of the normal dynamics of the patient's orthopedic structure.

Furthermore, Burns et $\mathrm{al}^{3}$ highlighted that products innovation introduced by the medical devices companies is considered one of the influential criteria of medical devices purchasing. Moreover, implant technology drives the orthopedic surgeons to select the implant which matches patient demand, high-technology implants to high-demand 
patients who may benefit from new expensive technology, and by providing objective guidelines for the use of less expensive joint implants for low-demand patients. ${ }^{25}$

Another study by Lingg et $\mathrm{al}^{13}$ emphasized that innovation is valued by orthopedic physicians as $47 \%$ of them reported that their clinical practice has been exposed to using an obsolete medical device technology, which is not providing the variety of solutions matching different patients' conditions.

\section{Price}

Bahadori et $\mathrm{al}^{16}$ stated that medical equipment price-related factors are low price of medical equipment, low price of accessories, and discount for each payment. Burns et $\mathrm{al}^{3}$ argued that the price of the joint implant has a moderate influence on the purchase decision.

\section{Methodology}

One of the aims of this study is to assess the most crucial attributes Influencing orthopedic physicians' decisions while purchasing medical devices and equipment from medical devices companies in Kuwaiti MOH hospitals.

By analyzing these factors, which are linked to physicians' preferences, their ranking and values will be obtained. This will allow the M\&S department in medical devices companies in Kuwait to build the optimum strategy of budget allocation and marketing plans, aiming to spend more money on the real factors that influence decision and decreasing the money-wasting on less influencing factors, which will be reflected positively on the organizations' profits. In addition, these findings will cover the gap in the literature.

Moreover, this study will provide a simulation tool that can predict physicians' decisions in case of having alternative product offers to find out physicians' trade-offs performed in weighing these offers for a final choice. Usually, these offers are submitted as bundles of many attributes. Additionally, from companies' perspectives, this study result will support M\&S department to augment product offers to be matching physicians' preferences.

\section{Methodological Framework Conceptual Framework}

To ensure the validity of our conceptual framework, SMEs from six medical devices companies were involved to validate all factors that came from the literature and to add any factor that may affect purchasing decisions from their point of view. They agreed on nine factors that came from the literature and had comments on others, some factors cannot be taken into consideration during the purchasing phase, as the purchasers usually buy different types of orthopedic implants to cover all patients' conditions related factors such as patient age, patient sex, patient weight, patient general health condition and the expected activity after the surgery. Therefore, the patient condition factor will not be evaluated. In addition, quality is unmeasurable also before purchase. Another factor cannot be used because it is difficult to be measured as trust.

\section{Proposed Framework}

Based on the previous data from literature and SMEs' validation, the framework has been built considering brand, price, after-sales service, innovations, sponsorship, implant review in journal, leader influence, technical support, and product training as the main factors influencing orthopedic surgeon's decision of purchasing medical devices and equipment with the consideration of physician's experience, nationality, and specialty as moderating variables.

\section{The Dependent Variable}

The orthopedic surgeons' decision of purchasing medical devices and equipment is the dependent variable as it is influenced by all factors.

\section{The Independent Variables}

Nine attributes represent the independent variables as the dependent variable is influenced by them, but they do not influence each other (Table 1). 
Table I Attributes and Levels

\begin{tabular}{|c|c|c|}
\hline Attribute & Level I & Level 2 \\
\hline Price & Reasonable price & High price \\
\hline Brand & Recognized brand & Unrecognized brand \\
\hline After sale service & Alternative device till fix the defected one & Device repair \\
\hline Sponsorship & Sponsoring surgeons to orthopedic conferences & Not applicable \\
\hline Implant review in journal & Adequate & Inadequate \\
\hline Innovations & More anatomical implants & Standard (universal) implants \\
\hline Leader influence & Recommended by superiors & Not recommended by superiors \\
\hline Technical support & On-site technician (sales representative) & Without on-site technician \\
\hline Product training & One-to-one training with well-known orthopedic surgeon & Hands-on training on bone models and cadavers \\
\hline
\end{tabular}

\section{The Moderating Variables}

The rate of adoption of new medical technologies and medical devices differs between the healthcare organizations, and this is due to the experience and knowledge of the physicians in adopting new technologies. ${ }^{26}$ Authors have argued that decision-making is highlighted and influenced by the personal characteristics of the physicians and their expertise in evaluating the clinical situation'..$^{27,28}$ This study follows Burns et $\mathrm{al}^{3}$ study where the moderating variables are working experience and specialty. In addition, nationality has been added as another moderating variable because of the diversity in physicians' nationalities working in Kuwait $\mathrm{MOH}$. These variables are 1) Working experience: refers to the number of years of working as an orthopedic surgeon. Which are 5 to 10,0 to 15,15 to 20 , and over 20 years. 2) Specialty: refers to the orthopedic specialty of the surgeons, which is trauma, arthroscopy, arthroplasty, or spine. 3) Nationality: surgeon's nationality, which is either Kuwaiti, Non-Kuwaiti Arabic, or Non-Kuwaiti Non-Arabic.

\section{Research Questions}

(1) What is the ranking of factors that influence orthopedic physicians' decision in purchasing medical devices and equipment in $\mathrm{MOH}$ hospitals in Kuwait?

(2) How can the marketing and sales department predict physicians' decisions before designing product proposals?

\section{Hypotheses Hypothesis I}

The brand is positively correlated to the choice of product offers for orthopedic physicians in MOH hospitals in Kuwait. A study made by Bahadori et $\mathrm{al}^{16}$ where the brand ranked second among four determinant criteria influencing the purchase of medical equipment.

\section{Hypothesis 2}

Price is positively correlated to the choice of product offers for orthopedic physicians in $\mathrm{MOH}$ hospitals in Kuwait. According to Buusman et al, ${ }^{29}$ drug price has a significant impact on physicians prescribing behavior. Moreover, Burns $\mathrm{et}^{3} \mathrm{l}^{3}$ argued that the price of the joint implant influences the purchase decision.

\section{Hypothesis 3}

After-sales service is positively correlated to the choice of product offers for orthopedic physicians in MOH hospitals in Kuwait. Bahadori et $\mathrm{al}^{16}$ study results ranked after-sale service third among the factors influencing the purchase decision of medical equipment. 


\section{Hypothesis 4}

Sponsorship is positively correlated to the choice of product offers for orthopedic physicians in MOH hospitals in Kuwait. In this regard, Sriwignarajaa and Fernando ${ }^{30}$ stated clearly that sponsorship is the highest influential factor of prescribing behavior. Conferences sponsorship is an important factor in the purchase decision as highlighted by Lakdawala. ${ }^{20}$

\section{Hypothesis 5}

Sales and service features are positively correlated to the choice of product offers for orthopedic physicians in $\mathrm{MOH}$ hospitals in Kuwait. In the light of Burns et $\mathrm{al}^{3}$ study, physicians not only prefer certain brands but also desire a high service level. Also, as per Felgner et $\mathrm{al}^{14}$ study results, physicians considered the service provided by medical companies in their decision-making.

\section{Hypothesis 6}

Implant technological features are positively correlated to the choice of product offers for orthopedic physicians in $\mathrm{MOH}$ hospitals in Kuwait. Felgner et $\mathrm{al}^{14}$ state that physicians assessed the evidence base when deciding whether to adopt the medical device.

\section{Hypothesis 7}

Technical support is positively correlated to the choice of product offers for orthopedic physicians in Kuwait. According to O'Connor et al, ${ }^{21}$ the device representatives and some surgeons believe that representatives benefit patient care, by increasing efficiency and mitigating deficiencies among operating room personnel (including the surgeons themselves). Additionally, Fugh-Berman and Ahari ${ }^{31}$ mentioned that one-to-one visit between medical representatives and physician is the main factor that leads to a sales increase of the pharmaceutical companies.

\section{Hypothesis 8}

Innovations are positively correlated to the choice of product offers for orthopedic physicians in $\mathrm{MOH}$ hospitals in Kuwait. According to Sampietro-Colom et al, ${ }^{23}$ innovation of the new medical equipment is one of the main determinant criteria in a purchase decision. Also, Burns et $\mathrm{al}^{3}$ highlighted that products innovation introduced by the medical devices companies is considered one of the influential criteria of medical devices purchasing.

\section{Hypothesis 9}

Opinion leaders are positively correlated to the choice of Product offers for orthopedic physicians in MOH hospitals in Kuwait. Lingg et $\mathrm{al}^{13}$ carried out multiple studies on orthopedic specialists who have to make purchase decisions regarding medical devices. They state that the orthopedic specialist who is working in a team environment tend to interact and involve others in their team in the purchasing process.

\section{Research Limitations}

The research will focus only on $\mathrm{MOH}$ hospitals in Kuwait and did not include private hospitals due to time constraints. As per SMEs validation, $90 \%$ of all orthopedic business is in $\mathrm{MOH}$ hospitals. Moreover, data of sales numbers of companies of Kuwait could not be shared due to confidentiality reasons.

\section{Conjoint Analysis \\ Definition}

Conjoint analysis (CA) is a significant tool that has been utilized to weigh purchasers' preferences for different characteristics of either services or products in different fields, for example, psychology, economics, and decisionmaking theories since the 1970 s. ${ }^{32}$

\section{Conjoint Analysis Types}

Three types of CA were listed by Orme $^{33}$ as cited in Alkoragaty ${ }^{34}$ which are conjoint value analysis (CVA), adaptive conjoint analysis (ACA), and choice-based conjoint analysis (CBC), while the fourth type was added by Rao ${ }^{35}$ named self-explicated conjoint analysis. 


\section{Selected Method}

A full-profile $\mathrm{CBC}$ method was selected due to more closeness to real-world decision-making and its strength at estimating preferences using up to 10 conjoint attributes. A full-profile conjoint method was chosen rather than a partial profile one since it can give a more representative choice task in the proposed survey. In case of making a decision about purchasing orthopedic medical devices or equipment, physicians are rarely subjected to a few features of the available products. Rather, they can depend on numerous product attributes to build the right decisions based on selecting the best offer bundle that will fulfill their requirements. There is no ideal conjoint method, Researcher has to assess the study condition and choose the method that reveals the way which the participants follow in decisionmaking. ${ }^{33}$

\section{Research Design}

The research will take the deductive approach and the quantitative method will be used to answer research questions. The quantitative method is used to accomplish objectivity and exclude subjectivity, which usually arises from the researcher's perceptions to avoid bias. On the contrary, the qualitative method is used to build an understanding of participants' perspectives so it is usually exploratory in its nature. ${ }^{36}$ Despite the small number of physicians (320), the quantitative method will be used in this study as all heads of departments in MOH hospitals refused to make one-to-one interviews and suggested only a questionnaire, which will be higher in confidentiality.

Consequently, a questionnaire will be used for data collection, which spent 2 weeks.A total of 240 questionnaires have been distributed via WhatsApp to orthopedic physicians in six MOH hospitals with a 50\% response rate. To analyze the collected data, I will use a conjoint analysis tool hosted by Sawtooth Lighthouse Studio software package V.9.6.1.

Johnson, who is the creator of Sawtooth Software's CBC System, has prescribed standard guidelines while calculating the least sample sizes for aggregate level

full-profile $\mathrm{CBC}$ modeling:

"nta/c $\geq 500 "$

$\mathrm{nta}=500 \times \mathrm{c}$

$\mathrm{n} \times 12 \times 2=500 \times 2$

$\mathrm{n}=1000 / 24$

$\mathrm{n}=41.6$ (ie, the minimal accepted respondents number is 42 )

where $\mathrm{n}$ is the participants' number, $\mathrm{t}$ is the tasks number, $\mathrm{a}$ is the alternatives number for each task but excluding the nonalternative, and $\mathrm{c}$ is the analysis cells number. While considering main effects, $\mathrm{c}$ is equivalent to the biggest number of levels for any one attribute. ${ }^{37}$

\section{Data Analysis and Findings Various Types of Analysis}

Orme $^{33}$ emphasized that there are different methods to analyze the $\mathrm{CBC}$ data. These methods are Hierarchical Bayes Estimation (HB). which collects data of each respondent separately to calculate the part-worth of everyone, Latent Class Analysis, Aggregate Choice Analysis, and Counting analysis, which provide an overall estimation of the main effects. The latter method focuses on the number of times the attribute levels are selected, while other methods depend on the part-worth estimations.

We will use HB to answer the research questions . Additionally, to answer the What-if question, I applied a market simulator. HB is faster than latent class analysis and characterized by a high level of accuracy compared to counting analysis. ${ }^{38}$ I used Sawtooth Lighthouse Studio software package V.9.6.1 to apply all previous methods of analysis on data collected from the responses of 120 completed surveys. 


\section{Overall Relative Importance (RI)}

HB analysis presents the Average Importance for all attributes, which answers the question, what is the ranking of factors based on their values that influence orthopedic Physicians in purchasing medical devices and equipment in $\mathrm{MOH}$ hospitals in Kuwait? (Table 2).

Based on the literature and SMEs discussion, physicians preferred the most beneficial level at each product factor. For instance, they chose a recognized brand with $60.66 \%$ on average over an unrecognized one.

Chi-square values in HB analysis represent the RI.

All attributes are significant as all p-values are less than 0.05; which means there is enough evidence to fail to reject the alternative hypotheses.

HB analysis has shown that the value of degree of freedom (DF) for the whole factor is equal to 2 . Orme, ${ }^{33}$ as cited in Alkoragaty, ${ }^{34}$ states that the DF theory refers to the least choice sets that participants can choose. As per the below equation:

$\mathrm{DF}=$ Total Numbers of levels - The Total Number of Attributes +1 (despite NO option)

Therefore, in this study, the degree of freedom $=2-1=1+1$ for no option $=2$ within each attribute.

\section{Comment on Each Attribute} Implant Review in Journal (RI: 15.8)

It is the most preferred attribute that attracts physicians to a product that matches the results of the study made by Felgner et al, ${ }^{14}$ where the state of medical care which includes medical guidelines was the first factor influencing the adoption of the medical devices by physicians. In addition, physicians discussed the available evidence extensively. On the contrary, Hatz et $\mathrm{al}^{4}$ did not recognize medical evidence as an important driver of the adoption of medical devices. For the standard deviation, it is clear that physicians slightly vary in their opinions regarding this attribute with a value of 11.56 standard deviation.

\section{Brand (RI: I5.74)}

The second preferred attribute is Brand specifically recognized ones. An untrusted environment and lack of confidence in unknown companies may explain why this attribute is crucial over the other attributes. So, physicians preferred a recognized brand to any other attribute except the previous one. This result supports Narendran and Narendranathan, ${ }^{17}$ where they state that prescription behavior is significantly influenced by the reputation of the company and the strength of brand names. Moreover, this study matches the result of Bahadori et $\mathrm{al}^{16}$ study where brand ranked second among four determinant criteria influencing the purchase of medical equipment.

Table 2 Overall Relative Importance

\begin{tabular}{|l|l|l|l|l|}
\hline Attribute & Importance & Standard Deviation & P-values & Note \\
\hline Implant Review in Journal & 15.80 & 11.56 & 0.000372 & Significant \\
\hline Brand & 15.74 & 10.38 & 0.000321 & Significant \\
\hline Leader Influence & 14.39 & 8.81 & 0.000858 & Significant \\
\hline Price & 11.19 & 7.08 & 0.003716 & Significant \\
\hline Technical Support & 10.07 & 7.02 & 0.008856 & Significant \\
\hline Sponsorship & 10.068 & 6.74 & 0.004629 & Significant \\
\hline Innovations & 8.69 & 7.89 & 0.014648 & Significant \\
\hline After Sales Service & 7.15 & 5.75 & 0.032005 & Significant \\
\hline Product Training & 6.90 & 5.84 & 0.0395 & Significant \\
\hline
\end{tabular}




\section{Leader Influence (RI: I4.39)}

Leader influence attribute is expressed by recommended products by superiors in the product offers. Physicians are so much tended to take recommendations from their leaders since most orthopedic physicians tend to rely on their colleagues or superiors to advise them.

Price (RI: II.19)

Unexpectedly, the price was in fourth place. This result shows how physicians think about product packages; they are no longer looking for one attribute. They are interested in a recognized brand, sufficient review in journals, and other product attributes. This unpredicted result of the price factor matched what has been mentioned by Sanyal et al ${ }^{18}$ when they emphasized that surgeons contemplate the cost and quality relationship, so they manage a price-quality evaluation before being decisive. On the contrary, Siddel as cited in Burns et $\mathrm{al}^{3}$ study results indicated that cost ranked second in physician preferences items research.

\section{Technical Support (RI: 10.07)}

The fifth preferred factor that influences physicians' decision is the technical support that was submitted to physicians either on-site sales rep. or without sales representative, HB analysis pointed to on-site sales representative level as a preferred level. Because there are many companies with many systems to use which have many tips and tricks that require help from the companies' representative. Thus, it is logical to stress the importance of technical support. And, as mentioned in the literature, some surgeons believe that reps benefit patient care, by increasing efficiency and mitigating deficiencies among operating room personnel (including the surgeons themselves). While Sriwignarajaa and Fernando ${ }^{30}$ mentioned that relation with medical representatives is ranked 3rd among five influential criteria of prescribing behavior.

\section{Sponsorship (RI:10.068)}

Sponsorship was the sixth factor. Note that the average importance of this factor is close to technical support value as physicians in Kuwait prefer companies that sponsor them for orthopedic conferences due to, they are passionate about their education investment as per SME's discussion. On the other hand, in another study made by Sriwignarajaa and Fernando $^{30}$ sponsorship was ranked first among the influential criteria of prescribing behavior.

\section{Innovation (RI:8.69)}

Innovation was the seventh factor. Physicians trade-off their anatomical implants for other attributes. In Burns et $\mathrm{al}^{3}$ study, innovation ranked third among the factors that matter to the orthopedic physicians in selecting medical devices.

\section{After-Sales Service (RI:7.I5)}

It was in the tail of the ranking which may mean that physicians trade-off their alternative device for other attributes. Value of this attribute reveals that orthopedic physicians did not interest in after-sales service attribute either device alternative or repair. This study results match to some extent the results of Bahadori et al ${ }^{16}$ study where after-sale service ranked third among four determinant criteria influencing the purchase of medical equipment.

\section{Product Training (RI:6.90)}

The lowest preferred attribute is product training. This is due to dependency on sales representatives who will be well trained and can scrub with surgeons. Unexpectedly to most orthopedic companies in Kuwait spend their budget mainly on sending surgeons for training as discussed with SMEs.

\section{Market Choice Simulator (What-if Analysis)}

This will be conducted by Sawtooth lighthouse studio package V.9.6.1 which will predict physician decisions about product offers that had not been included in the survey. Therefore, this will achieve one of the research objectives to expect physician decision for any expected combination of attribute levels to help M\&S department to design convenient offers. 


\section{First Simulation}

Knowing the lowest product package in terms of organizational cost will maximize the physicians 'attractiveness by designing a reference offer. This reference offer consists of all the highest benefit levels that physicians may need which represent the high costly levels. Then, we will create five product packages with various factor levels to measure them with the reference offer via a Market simulator. According to data obtained from HB analysis, the least four important factors are after-sales service, product training, innovation, and sponsorship. So, we will make these four attributes unchanging in the five proposals that I assume will be beneficial to be the least cost on the company. Five packages, in addition, reference one is illustrated (Table 3).

Results have shown the highest preferred proposal will be the reference and this is due to it is containing the highest beneficial bundle that physicians can have. In addition, this result confirms that the data is accurate. Moreover, if five proposals have been distributed to orthopedic physicians, the highest preferred proposal will be the fifth one, which has $19 \%$ of shares preference. Offer five proposed that they can work without a sales rep. and spend money on other most preferred factors. Thus, the company will use a simulator to expect the physician decision and design another offer, which makes other competitors cannot compete with them (Figure 1).

\section{Second Simulation}

In this simulation, we will use offer five as a reference proposal. This reference one will maintain the lowest five important attributes at their least utility levels and keep the highest four important attributes at the highest utility levels. Then I create four proposals in which I adjust the level of the highest four crucial attributes once at each offer. For instance, the first proposal will contain only a high price level and maintain the other attributes unchangingly. The second proposal will contain only inadequate implant review in a journal and maintain also the other attributes unchanging. The third proposal will contain an unrecognized brand. In the end, the fourth one will contain not recommended by leaders. After that we conduct the simulation and based on the result from HB analysis, it will be the input data for the simulation (Table 4).

The result has shown that the most preferred proposal is number one in which the price has been adjusted to a higher price and other attributes unchanged. Moreover, this will minimize the attractiveness from $19 \%$ to $15 \%$ of shares preference (Figure 2) (Table 5).

\section{Third Simulation}

Following the same steps, proposal one will be the reference offer. Thereby, we designed three proposals by changing the highest three preferred factors and keeping other attribute levels fixed (Figure 3) (Table 6).

\section{Fourth Simulation}

In the end, to find the next least factor level that has the lowest impact on the physicians' attractiveness to product proposals. We built proposal three as a reference offer that means that we included leader influence factor to the unchanged factors. Thus, we designed two proposals by changing the highest two preferred factors and keeping other attribute levels fixed (Tables 7 and 8).

\section{Discussion and Findings}

\section{For the First Question: What is the Ranking of Factors That Influence Orthopedic Physician Decision in} Purchasing Medical Devices and Equipment in MOH Hospitals in Kuwait?

Based on research findings, implant review in a journal, brand, leader influence, price, technical support, sponsorship, innovation, after-sales service, and product training, respectively, have a significant impact on the orthopedic physician decision of purchasing medical devices and equipment in $\mathrm{MOH}$ hospitals in Kuwait. This is due to the relative importance that had been given by the physicians to the various product attributes that help in factor ranking.

Implant review in a journal is the most preferred factor that attracts orthopedic physicians to a certain product where sufficient implant review in a journal is the most preferred attribute level.

Moreover, even if orthopedic physicians were offered a branded product but with insufficient reviews in a journal, they would not decide to buy it. This enlightens the fact that physicians follow the medical evidence in adopting medical devices and equipment for the purpose of providing the right device matching the patients' demands. 
Table 3 Illustration of Five Packages in Addition to Reference One

\begin{tabular}{|c|c|c|c|c|c|c|c|c|c|}
\hline Label & Price & Brand & $\begin{array}{l}\text { After Sales } \\
\text { Service }\end{array}$ & Sponsorship & $\begin{array}{l}\text { Implant } \\
\text { Review in } \\
\text { Journal }\end{array}$ & Innovations & $\begin{array}{l}\text { Leader } \\
\text { Influence }\end{array}$ & Technical Support & $\begin{array}{l}\text { Product } \\
\text { Training }\end{array}$ \\
\hline Referencel & Reasonable price & Recognized brand & Device repair & Not applicable & Adequate & $\begin{array}{l}\text { Standard (universal) } \\
\text { implants }\end{array}$ & $\begin{array}{l}\text { Recommended } \\
\text { by superiors }\end{array}$ & $\begin{array}{l}\text { On-site technician (sales } \\
\text { representative) }\end{array}$ & $\begin{array}{l}\text { Hands on training } \\
\text { on bone models } \\
\text { and cadavers }\end{array}$ \\
\hline Proposal I & High price $^{\mathrm{a}}$ & Recognized brand & Device repair & Not applicable & Adequate & $\begin{array}{l}\text { Standard (universal) } \\
\text { implants }\end{array}$ & $\begin{array}{l}\text { Recommended } \\
\text { by superiors }\end{array}$ & $\begin{array}{l}\text { On-site technician (sales } \\
\text { representative) }\end{array}$ & $\begin{array}{l}\text { Hands on training } \\
\text { on bone models } \\
\text { and cadavers }\end{array}$ \\
\hline Proposal 2 & Reasonable price & Recognized brand & Device repair & Not applicable & Inadequate ${ }^{a}$ & $\begin{array}{l}\text { Standard (universal) } \\
\text { implants }\end{array}$ & $\begin{array}{l}\text { Recommended } \\
\text { by superiors }\end{array}$ & $\begin{array}{l}\text { On-site technician (sales } \\
\text { representative) }\end{array}$ & $\begin{array}{l}\text { Hands on training } \\
\text { on bone models } \\
\text { and cadavers }\end{array}$ \\
\hline Proposal 3 & Reasonable price & $\begin{array}{l}\text { Unrecognized } \\
\text { brand }^{\mathrm{a}}\end{array}$ & Device repair & Not applicable & Adequate & $\begin{array}{l}\text { Standard (universal) } \\
\text { implants }\end{array}$ & $\begin{array}{l}\text { Recommended } \\
\text { by superiors }\end{array}$ & $\begin{array}{l}\text { On-site technician (sales } \\
\text { representative) }\end{array}$ & $\begin{array}{l}\text { Hands on training } \\
\text { on bone models } \\
\text { and cadavers }\end{array}$ \\
\hline Proposal 4 & Reasonable price & Recognized brand & Device repair & Not applicable & Adequate & $\begin{array}{l}\text { Standard (universal) } \\
\text { implants }\end{array}$ & $\begin{array}{l}\text { Not } \\
\text { recommended } \\
\text { by superiors }{ }^{\mathrm{a}}\end{array}$ & $\begin{array}{l}\text { On-site technician (sales } \\
\text { representative) }\end{array}$ & $\begin{array}{l}\text { Hands on training } \\
\text { on bone models } \\
\text { and cadavers }\end{array}$ \\
\hline Proposal 5 & Reasonable price & Recognized brand & Device repair & Not applicable & Adequate & $\begin{array}{l}\text { Standard (universal) } \\
\text { implants }\end{array}$ & $\begin{array}{l}\text { Recommended } \\
\text { by superiors }\end{array}$ & $\begin{array}{l}\text { Without on-site } \\
\text { technician }^{\mathrm{a}}\end{array}$ & $\begin{array}{l}\text { Hands on training } \\
\text { on bone models } \\
\text { and cadavers }\end{array}$ \\
\hline
\end{tabular}

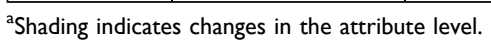


Table 4 Illustration of Four Packages in Addition to Reference 2

\begin{tabular}{|c|c|c|c|c|c|c|c|c|c|}
\hline Label & Price & Brand & $\begin{array}{l}\text { After Sales } \\
\text { Service }\end{array}$ & Sponsorship & $\begin{array}{l}\text { Implant Review } \\
\text { in Journal }\end{array}$ & Innovations & Leader Influence & $\begin{array}{l}\text { Technical } \\
\text { Support }\end{array}$ & Product Training \\
\hline Reference 2 & $\begin{array}{l}\text { Reasonable } \\
\text { price }\end{array}$ & $\begin{array}{l}\text { Recognized } \\
\text { brand }\end{array}$ & $\begin{array}{l}\text { Device } \\
\text { repair }\end{array}$ & $\begin{array}{l}\text { Not } \\
\text { applicable }\end{array}$ & Adequate & $\begin{array}{l}\text { Standard (universal) } \\
\text { implants }\end{array}$ & $\begin{array}{l}\text { Recommended by } \\
\text { superiors }\end{array}$ & $\begin{array}{l}\text { Without On- } \\
\text { site technician }\end{array}$ & $\begin{array}{l}\text { Hands on training on bone } \\
\text { models and cadavers }\end{array}$ \\
\hline Proposal I & High price ${ }^{a}$ & $\begin{array}{l}\text { Recognized } \\
\text { brand }\end{array}$ & $\begin{array}{l}\text { Device } \\
\text { repair }\end{array}$ & $\begin{array}{l}\text { Not } \\
\text { applicable }\end{array}$ & Adequate & $\begin{array}{l}\text { Standard (universal) } \\
\text { implants }\end{array}$ & $\begin{array}{l}\text { Recommended by } \\
\text { superiors }\end{array}$ & $\begin{array}{l}\text { Without On- } \\
\text { site technician }\end{array}$ & $\begin{array}{l}\text { Hands on training on bone } \\
\text { models and cadavers }\end{array}$ \\
\hline Proposal 2 & $\begin{array}{l}\text { Reasonable } \\
\text { price }\end{array}$ & $\begin{array}{l}\text { Recognized } \\
\text { brand }\end{array}$ & $\begin{array}{l}\text { Device } \\
\text { repair }\end{array}$ & $\begin{array}{l}\text { Not } \\
\text { applicable }\end{array}$ & Inadequate $^{\mathrm{a}}$ & $\begin{array}{l}\text { Standard (universal) } \\
\text { implants }\end{array}$ & $\begin{array}{l}\text { Recommended by } \\
\text { superiors }\end{array}$ & $\begin{array}{l}\text { Without On- } \\
\text { site technician }\end{array}$ & $\begin{array}{l}\text { Hands on training on bone } \\
\text { models and cadavers }\end{array}$ \\
\hline Proposal 3 & $\begin{array}{l}\text { Reasonable } \\
\text { price }\end{array}$ & $\begin{array}{l}\text { Unrecognized } \\
\text { brand }^{\mathrm{a}}\end{array}$ & $\begin{array}{l}\text { Device } \\
\text { repair }\end{array}$ & $\begin{array}{l}\text { Not } \\
\text { applicable }\end{array}$ & Adequate & $\begin{array}{l}\text { Standard (universal) } \\
\text { implants }\end{array}$ & $\begin{array}{l}\text { Recommended by } \\
\text { superiors }\end{array}$ & $\begin{array}{l}\text { Without On- } \\
\text { site technician }\end{array}$ & $\begin{array}{l}\text { Hands on training on bone } \\
\text { models and cadavers }\end{array}$ \\
\hline Proposal 4 & $\begin{array}{l}\text { Reasonable } \\
\text { price }\end{array}$ & $\begin{array}{l}\text { Recognized } \\
\text { brand }\end{array}$ & $\begin{array}{l}\text { Device } \\
\text { repair }\end{array}$ & $\begin{array}{l}\text { Not } \\
\text { applicable }\end{array}$ & Adequate & $\begin{array}{l}\text { Standard (universal) } \\
\text { implants }\end{array}$ & $\begin{array}{l}\text { Not recommended } \\
\text { by superiors }{ }^{\mathrm{a}}\end{array}$ & $\begin{array}{l}\text { Without On- } \\
\text { site technician }\end{array}$ & $\begin{array}{l}\text { Hands on training on bone } \\
\text { models and cadavers }\end{array}$ \\
\hline
\end{tabular}

${ }^{a}$ Shading indicates changes in the attribute level. 
Table 5 Share Preference of Second Simulation

\begin{tabular}{|l|l|l|l|l|}
\hline Label & Shares of Preference & Standard Error & Lower 95\% CL & Upper 95\% CL \\
\hline Reference 2 & $33.0 \%$ & $2.3 \%$ & $28.5 \%$ & $37.4 \%$ \\
\hline Proposal I & $15.0 \%$ & $1.5 \%$ & $12.1 \%$ & $17.9 \%$ \\
\hline Proposal 2 & $12.7 \%$ & $1.5 \%$ & $9.7 \%$ & $15.7 \%$ \\
\hline Proposal 3 & $11.0 \%$ & $1.4 \%$ & $8.3 \%$ & $13.8 \%$ \\
\hline Proposal 4 & $14.2 \%$ & $1.7 \%$ & $10.9 \%$ & $17.5 \%$ \\
\hline
\end{tabular}

Table 6 Illustration of Three Packages in Addition to Reference 3

\begin{tabular}{|l|l|l|l|l|l|l|l|l|l|}
\hline Label & Price & Brand & $\begin{array}{l}\text { After } \\
\text { Sales } \\
\text { Service }\end{array}$ & Sponsorship & $\begin{array}{l}\text { Implant } \\
\text { Review in } \\
\text { Journal }\end{array}$ & Innovations & $\begin{array}{l}\text { Leader } \\
\text { Influence }\end{array}$ & $\begin{array}{l}\text { Technical } \\
\text { Support }\end{array}$ & $\begin{array}{l}\text { Product } \\
\text { Training }\end{array}$ \\
\hline Reference 3 & $\begin{array}{l}\text { High } \\
\text { price }\end{array}$ & $\begin{array}{l}\text { Recognized } \\
\text { brand }\end{array}$ & $\begin{array}{l}\text { Device } \\
\text { repair }\end{array}$ & $\begin{array}{l}\text { Not } \\
\text { applicable }\end{array}$ & Adequate & $\begin{array}{l}\text { Standard } \\
\text { (universal) } \\
\text { implants }\end{array}$ & $\begin{array}{l}\text { Recommended } \\
\text { by superiors }\end{array}$ & $\begin{array}{l}\text { Without } \\
\text { on-site } \\
\text { technician }\end{array}$ & $\begin{array}{l}\text { Hands on } \\
\text { training on bone } \\
\text { models and } \\
\text { cadavers }\end{array}$ \\
\hline Proposal I & $\begin{array}{l}\text { High } \\
\text { price }\end{array}$ & $\begin{array}{l}\text { Recognized } \\
\text { brand }\end{array}$ & $\begin{array}{l}\text { Device } \\
\text { repair }\end{array}$ & $\begin{array}{l}\text { Not } \\
\text { applicable }\end{array}$ & Inadequate & $\begin{array}{l}\text { Standard } \\
\text { (universal) } \\
\text { implants }\end{array}$ & $\begin{array}{l}\text { Recommended } \\
\text { by superiors }\end{array}$ & $\begin{array}{l}\text { Without } \\
\text { on-site } \\
\text { technician }\end{array}$ & $\begin{array}{l}\text { Hands on } \\
\text { training on bone } \\
\text { models and } \\
\text { cadavers }\end{array}$ \\
\hline Proposal 2 & $\begin{array}{l}\text { High } \\
\text { price }\end{array}$ & $\begin{array}{l}\text { Unrecognized } \\
\text { brand }\end{array}$ & $\begin{array}{l}\text { Device } \\
\text { repair }\end{array}$ & $\begin{array}{l}\text { Not } \\
\text { applicable }\end{array}$ & Adequate & $\begin{array}{l}\text { Standard } \\
\text { (universal) } \\
\text { implants }\end{array}$ & $\begin{array}{l}\text { Recommended } \\
\text { by superiors }\end{array}$ & $\begin{array}{l}\text { Without } \\
\text { on-site } \\
\text { technician }\end{array}$ & $\begin{array}{l}\text { Hands on } \\
\text { training on bone } \\
\text { models and } \\
\text { cadavers }\end{array}$ \\
\hline Proposal 3 & $\begin{array}{l}\text { High } \\
\text { price }\end{array}$ & $\begin{array}{l}\text { Recognized } \\
\text { brand }\end{array}$ & $\begin{array}{l}\text { Device } \\
\text { repair }\end{array}$ & $\begin{array}{l}\text { Not } \\
\text { applicable }\end{array}$ & Adequate & $\begin{array}{l}\text { Standard } \\
\text { (universal) } \\
\text { implants }\end{array}$ & $\begin{array}{l}\text { Not } \\
\text { recommended } \\
\text { by superiors }\end{array}$ & $\begin{array}{l}\text { Without } \\
\text { on-site } \\
\text { technician }\end{array}$ & $\begin{array}{l}\text { Hands on } \\
\text { training on bone } \\
\text { models and } \\
\text { cadavers }\end{array}$ \\
\hline
\end{tabular}

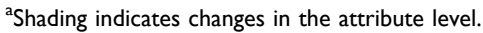

Furthermore, the second preferred attribute is brand, specifically a recognized one. Because physicians preferred recognized brands that provide them with more credibility and confidence, which will impact patients' outcomes.

In addition, physicians gave more importance to certain factors such as leader influence, this may be because orthopedic physicians tend to consider the opinion of the head of the department in devices selection. Moreover, they are used to ask their peers' opinions about the devices' postoperative results to decide the right devices to use.

While factor level like reasonable price which ranked fourth in this study results is no longer found as important alone, it should be submitted with other factors that physicians value nowadays according to their preferences and needs.

Finally, all nine factors are significant with various importance levels.

\section{For the Second Question: How Can Marketing and Sales Management Predict Orthopedic Physicians" Decisions Before Designing Product Proposals?}

This will assist M\&S department to create proposals that satisfy orthopedic physicians through expecting physicians ${ }^{\circ}$ decisions on various alternatives.

Choice simulation has been used to create the reference product profile and design new product proposals, which may be submitted to physicians. It weighs the alternatives depending on the reference offer and as per the information 
Table 7 Illustration of Two Packages in Addition to Reference 4

\begin{tabular}{|c|c|c|c|c|c|c|c|c|c|}
\hline Label & Price & Brand & $\begin{array}{l}\text { After Sales } \\
\text { Service }\end{array}$ & Sponsorship & $\begin{array}{l}\text { Implant } \\
\text { Review in } \\
\text { Journal }\end{array}$ & Innovations & Leader Influence & $\begin{array}{l}\text { Technical } \\
\text { Support }\end{array}$ & $\begin{array}{l}\text { Product } \\
\text { Training }\end{array}$ \\
\hline Reference 4 & High price & Recognized brand & Device repair & Not applicable & Adequate & $\begin{array}{l}\text { Standard (universal) } \\
\text { implants }\end{array}$ & $\begin{array}{l}\text { Not recommended by } \\
\text { superiors }\end{array}$ & $\begin{array}{l}\text { Without on-site } \\
\text { technician }\end{array}$ & $\begin{array}{l}\text { Hands on training } \\
\text { on bone models } \\
\text { and cadavers }\end{array}$ \\
\hline Proposal I & High price & Recognized brand & Device repair & Not applicable & Inadequate $^{d}$ & $\begin{array}{l}\text { Standard (universal) } \\
\text { implants }\end{array}$ & $\begin{array}{l}\text { Not recommended by } \\
\text { superiors }\end{array}$ & $\begin{array}{l}\text { Without on-site } \\
\text { technician }\end{array}$ & $\begin{array}{l}\text { Hands on training } \\
\text { on bone models } \\
\text { and cadavers }\end{array}$ \\
\hline Proposal 2 & High price & $\begin{array}{l}\text { Unrecognized } \\
\text { brand'('Shading } \\
\text { indicates changes } \\
\text { in the attribute } \\
\text { level.) }\end{array}$ & Device repair & Not applicable & Adequate & $\begin{array}{l}\text { Standard (universal) } \\
\text { implants }\end{array}$ & $\begin{array}{l}\text { Not recommended by } \\
\text { superiors }\end{array}$ & $\begin{array}{l}\text { Without on-site } \\
\text { technician }\end{array}$ & $\begin{array}{l}\text { Hands on training } \\
\text { on bone models } \\
\text { and cadavers }\end{array}$ \\
\hline
\end{tabular}

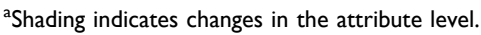


Table 8 Share Preference of Fourth Simulation

\begin{tabular}{|l|l|l|l|l|}
\hline Label & Shares of Preference & Standard Error & Lower 95\% CL & Upper 95\% CL \\
\hline Reference 4 & $32.9 \%$ & $1.6 \%$ & $29.7 \%$ & $36.1 \%$ \\
\hline Proposal I & $15.8 \%^{\mathrm{a}}$ & $1.7 \%^{\mathrm{a}}$ & $12.4 \%^{\mathrm{a}}$ & $19.2 \%^{\mathrm{a}}$ \\
\hline Proposal 2 & $15.3 \%$ & $1.7 \%$ & $11.9 \%$ & $18.7 \%$ \\
\hline
\end{tabular}

${ }^{a}$ Shading indicates the proposal with the higher shares of preference and other factors.

resulting from HB analysis. Accordingly, this simulation will enlighten the way of M\&S department toward minimizing the product offer cost while keeping physicians' desirability of this product.

Generally, all nine factors are retrieved from literature and validated with SMEs. In addition, only factors about Kuwait's environment context have been chosen.

$\mathrm{CBC}$ analysis had been chosen to give us the findings for this research and provide simulation for product offers resembling the ones that presented in real-life situations. $\mathrm{CBC}$ can measure utility scores of attributes levels, which are considered the backbone of conjoint analysis.

\section{Conclusion}

There is a good opportunity for all medical devices companies, after discussion with SMEs, either for growth or leaving stagnation phase. This opportunity resulted from Kuwait's investment plan in the MOH hospitals sector by allocating $\$ 4.2$ billion to build nine new MOH hospitals and by awarding \$11 billion for new healthcare infrastructure, which will require procurement of new medical devices and equipment. In addition, SMEs have no real understanding of what factors matter to the orthopedic physicians' decision in purchasing medical devices and equipment.

Thus, one of the goals of this research is to give M\&S departments in medical devices companies recommendations that will help them in forming attractive product offers to orthopedic physicians in $\mathrm{MOH}$ hospitals in Kuwait. Moreover, predicting the response from them in the future. To achieve these aims, the research aimed to assess the most significant attributes that orthopedic physicians value while trading off between product offers. Since physicians did not weigh each product characteristic independently; they think about the submitted offer as an entire package where their decisions are built on the most valuable characteristic that matches their preferences and their current needs.

Furthermore, the average importance of each attribute was computed. This will provide M\&S department with a clear picture of the most vital factors that they should take in their consideration while preparing offers. In addition, four simulation scenarios have been conducted in this research to reach the best economic offer that maintains physicians' attractiveness.

\section{Recommendations}

Based on the above findings, M\&S department needs to create a different way when they design product offers nowadays, as it had been noticed that for instance, including a reasonable price by itself will be insufficient in product offers. This means that product offers should include the attributes, which fulfill physicians' desires. Price alone is no more considered important in physicians' decisions of adopting certain products. They depend on other attributes during the evaluation of the proposed offers. In this study, they showed a high desirability level to certain factors such as recognized brand name and sufficient implant review in a journal. These two factors are considered the most important factors to orthopedic physicians in Kuwait. Therefore, submitting enough scientific evidence about products and their efficacy and output toward patients, in addition to a recognized brand must be included in a future proposal.

Reaching this point, in case of competition (price war) between companies, the company with the better overall bundle will attract the physician in case of a similar or a marginal price difference. In addition, different companies need to take into their consideration the positive effect of the leader's influence on physician preferences while purchasing a product, as it has been noticed that physicians prefer products with high recommendations from leaders that require workshops and good demonstrations starting by KOLs before other physicians. 
In addition, providing technical support in the shape of an on-site sales rep. will be of great value to physicians, as they do not know all tips and tricks for all companies' systems and as per result, they are not interested in product training due to dependency on the medical representative. Thus, adding this attribute to the offer will give it additional importance and value. Accordingly, it is advised that the $M \& S$ department should take into consideration all previous attributes while designing product offers. On the other hand, less value should be given to an attribute like product training and after-sales service, as they are factors that physicians do not rely on them in purchasing due to the presence of a sales rep. or depending on other devices till fix defected one. Thus, M\&S department needs to decrease their expenditures on both of them and give other factors more budget.

Second, the choice simulator will expect physicians' choices and will provide M\&S department with a realistic overview of physicians' preferences. This will guide M\&S department during offers designing. Moreover, the choice simulator can be a guidance for companies, as it can show the pros and cons of the submitted offer against other companies' offers. Finally, it provides a negotiation space between the company and physicians, by decreasing the final offer cost as much as possible while keeping the physicians satisfied. This will happen by selecting the less preferred factor level of the least valuable one to the physician like after-sales service, product training, and innovation.

And vice versa, to increase physicians 'preference for product offers, companies should select the most preferred factor level of the highest value ones.

\section{Future Research}

First, using conjoint analysis $\mathrm{CBC}$ technique can be conducted in the private sector on orthopedic physicians. Because the Kuwaiti government will provide all retired Kuwaiti insurance to be used in private hospitals. In addition to its plan to offer insurance for all expatriates by 2020 to be used with private hospitals. In other words, they will depend on private sectors to alleviate efforts on MOH hospitals. This study will help the medical devices companies also to assess factors that private orthopedic physicians value more to have a clear picture about the most crucial factors that will support purchase decisions for any product in the private market.

Second, the same research can be applied in all Gulf Cooperation Council to include all orthopedic physicians who are working in $\mathrm{MOH}$. This will be beneficial as different cultural contexts will be tested to explore similarities and differences between gulf countries. In other words, the result of this research may give us more validity and reliability.

Third, the same research can be applied by conjoint analysis with rating-based methods. This will help to explore any differences in the result between choice and rating-based methods in the same context.

\section{Abbreviations}

\section{ACA Adaptive Conjoint Analysis}

CA Conjoint Analysis

CAGR Compound Annual Growth Rate

CBC Choice-Based Conjoint

CL Confidence Level

CMS Central Medical Stores

CVA Conjoint Value-Based Analysis

DF Degree of Freedom

HB Hierarchical Bayes Estimation

HRMD High-Risk Medical Device

KOLs Key Opinion Leaders

M\&S Marketing and Sales

MOH Ministry of Health

OR Operation Room

PACI Public Authority for Civil Information

RI Relative Importance

S\&P Standard \& Poor's

SME Subject Matter Experts 


\section{Disclosure}

The authors report no conflicts of interest in this work.

\section{References}

1. tenlivegroup. tenlivegroup; January, 2018. Available from: https:/tenlivegroup.com/kuwait-healthcare-sector-set-grow-2020/. Accessed April, 2019.

2. oxfordbusinessgroup. n.d.. Available from: https://oxfordbusinessgroup.com/overview/balanced-diet-government-seeks-give-health-caresustainable-future. Accessed April 3, 2019.

3. Burns LR, Housman MG, Booth R, Koenig A. Physician preference items: what factors matter to surgeons? Does the vendor matter? Med Devices (Auckl). 2018;11:39-49. doi:10.2147/MDER.S151647

4. Hatz M, Sonnenschein T, Blankart C. Value in health. PMA Scale. 2017;20(4):533-541.

5. Obremskey W, Dail T, Jahangir A. Value-based purchasing of medical devices. Clin Orthopaedics Related Res. 2012;470(4):1054-1064. doi:10.1007/s11999-011-2147-9

6. Montgomery K, Schneller E. Hospitals' strategies for orchestrating selection of physician preference items. Milbank Q. 2007;85(2):307-335. doi:10.1111/j.1468-0009.2007.00489.x

7. ITA. International trade administration; 2018. Available from: https://www.export.gov/apex/article2?id=Kuwait-Medical-and-Surgical-Equipment. Accessed January 7, 2022.

8. Bhagria. Medical Equipment and Devices. Henry B. Tippie school of Management; February 8, 2017.

9. Stanfield P. Medical supplies and equipment for primary health care. A practical resource for procurement and management. Trans $R$ Soc Trop Med Hyg. 2002;96:4. doi:10.1016/S0035-9203(02)90398-6

10. World Health Organization. Introduction to medical equipment inventory management. "Medicines Pricing and Financing"; 2011. Available from: https://www.who.int/medicines/areas/access/en/. Accessed February 16, 2019.

11. Schacter D, Gilbert D, Wegner D, Hood B. Psychology European Edition. New York, United States: Macmillan International Higher Education; 2011.

12. Oliveira A. A discussion of rational and psychological decision-making theories and models: the search for a cultural-ethical decision-making model. Electr J Business Ethics Organ Stud. 2007;12(2):12-17.

13. Lingg M, Merida-Herrera E, Wyss K, Durán-Arenas L. Attitudes of orthopedic specialists toward effects of medical device purchasing. Int J Technol Assess Health Care. 2017;33(1):46-53. doi:10.1017/S0266462317000101

14. Felgner S, Ex P, Henschke C. Physicians' decision making on adoption of new technologies and role of coverage with evidence development: a qualitative study. Value Health. 2018;21(9):1069-1076. doi:10.1016/j.jval.2018.03.006

15. Moss G, Colman A. Choices and preferences: experiments on gender differences. J Brand Manage. 2001;9(2):89-98. doi:10.1057/palgrave. bm. 2540057

16. Bahadori M, Sadeghifar J, Ravangard R, Salimi M, Mehrabian F. Priority of determinants influencing the behavior of purchasing the capital medical equipments using AHP model. World J Med Sci. 2012;7(3):131-136.

17. Narendran R, Narendranathan M. Influence of pharmaceutical marketing on prescription practices of physicians. J Ind Med Assoc. 2013;111 (1):47-50.

18. Sanyal S, Datta S, Banerjee A. Conceptualization of branding: strategy based on the Indian pharma sector. Int J Pharm Healthcare Marketing. 2013;7(2):175-198. doi:10.1108/IJPHM-04-2013-0013

19. Chao C, Cheng B. Factors influencing the future relationship of hospital procurement staff with medical device suppliers. Social Behav Personal. 2012;40(6):945-957. doi:10.2224/sbp.2012.40.6.945

20. Taneja G. Impact of pharmaceutical industry promotion mix on doctor's prescribing behaviour. Asia Pac Business Rev. 2008;4(4):82-95. doi: $10.1177 / 097324700800400408$

21. O'Connor B, Pollner F, Fugh-Berman A. Salespeople in the surgical suite: relationships between surgeons and medical device representatives. PLoS One. 2016;11(8). doi:10.1371/journal.pone.0158510

22. Healy W, Ayers M, Iorio R, Patch D, Appleby D, Pfeifer B. Impact of a clinical pathway and implant standardization on total hip arthroplasty: a clinical and economic study of short-term patient outcome. J Arthroplasty. 1998;13(3):266-276. doi:10.1016/S0883-5403(98)90171-1

23. Sampietro-Colom L, Morilla-Bachs I, Gutierrez-Moreno S, Gallo P. Development and Test of a decision support tool for hospital health technology assessment. Int J Technol Assess Health Care. 2012;28(4):460-465. doi:10.1017/S0266462312000487

24. Chandy RK, Tellis GJ. Organizing for radical product innovation: the overlooked role of willingness to cannibalize. J Marketing Res. 1998;35 (4):474-487. doi:10.1177/002224379803500406

25. Healy WL, Iorio R. Implant selection and cost for total joint arthroplasty: conflict between surgeons and hospitals. Clin Orthopaedics Related Res. 2007;457:57-63. doi:10.1097/BLO.0b013e31803372e0

26. Rothery C, Claxton K, Palmer S, Epstein D, Tarricone R, Sculpher M. Characterising uncertainty in the assessment of medical devices and determining future research needs. Health Econ. 2017;26:109-123. doi:10.1002/hec.3467

27. Salpeter S, Malter D, Luo E, Lin A, Stuart B. Systematic review of cancer presentations with a median survival of six months or less. $J$ Palliat Med. 2012;15(2):175-185. doi:10.1089/jpm.2011.0192

28. Karnik S, Kanekar A. Ethical issues surrounding end-of-life care: a narrative review. Healthcare. 2016;4(2):24. doi:10.3390/healthcare4020024

29. Buusman A, Andersen M, Merrild C, Elverdam B. Factors influencing GPs' choice between drugs in a therapeutic drug group. A qualitative study. Scand J Prim Health Care. 2007;25(4):208-213. doi:10.1080/02813430701652036

30. Sriwignarajaa K, Fernando PM. Factors affecting on pharmaceutical products brand promotions: a study on professional endorsement perspective. 6th International Conference on Business \& Information ICBI. Sri Lanka: Faculty of Commerce and Management Studies, University of Kelaniya; 2015: 441-448.

31. Fugh-Berman A, Ahari S. Following the script: how drug reps make friends and influence doctors. PLoS Med. 2007;4(4):e150. doi:10.1371/journal. pmed.0040150 
32. Green P, Srinivasan V. Conjoint analysis in consumer research: issues and outlook. J Consumer Res. 1978;5(2):103-123. doi:10.1086/208721

33. Orme B. Interpreting the Results of Conjoint Analysis, Getting Started with Conjoint Analysis: Strategies for Product Design and Pricing Research 2nd Edition. Madison, WI: Research Publishers LLC; 2010.

34. Alkoragaty A. Exploring Expatriate Employees Preferences While Selecting Jobs in Kuwait Using Conjoint Analysis; 2017.

35. Rao VR. Applied Conjoint Analysis. New York: Springer; 2014.

36. Punch, K. (2005), "Introduction to Social Research: Quantitative \& Qualitative Approaches (2nd Ed)", London; Thousand Oaks, CA: Sage Publications. Retrieved July 22, 2018. Available from: https://books.google.com.kw/books?printsec=frontcover\&vid=ISBN0761944176\&redir_esc=y\#v=one

37. Johnson R, Orme B. Getting the most from CBC. Sequim: Sawtooth Software Research Paper Series, Sawtooth Software; 2003.

38. McCullough RP. Comparing hierarchical Bayes and latent class choice: practical issues for sparse data sets. 2009 Sawtooth Software Conference Proceedings, Delray Beach (FL); 2009.

\section{Publish your work in this journal}

Medical Devices: Evidence and Research is an international, peer-reviewed, open access journal that focuses on the evidence, technology, research, and expert opinion supporting the use and application of medical devices in the diagnosis, monitoring, treatment and management of clinical conditions and physiological processes. The identification of novel devices and optimal use of existing devices which will lead to improved clinical outcomes and more effective patient management and safety is a key feature of the journal. The manuscript management system is completely online and includes a very quick and fair peer-review system. Visit http://www.dovepress.com/testimonials.php to read real quotes from published authors.

Submit your manuscript here: https://www.dovepress.com/medical-devices-evidence-and-research-journal 